\title{
Implications of the cementation of beach sediments for the recreational use of the beach
}

\author{
Michalis I. Vousdoukas ${ }^{1,}$, Adonis F. Velegrakis ${ }^{a}$, Areti Kontogianni ${ }^{\mathrm{a}}$, and Efstratia-Natalia \\ Makrykosta ${ }^{a}$
}

\footnotetext{
${ }^{a}$ Department of Marine Science, University of the Aegean, University Hill, Mytilini 81100, Greece

${ }^{1}$ Present address: IFREMER, Département Biogéochimie et Ecotoxicologie. Station marine d' Endoume, Chemin de la Batterie des Lions, 13007, Marseille, France
}

*: Corresponding author: Michalis I. Vousdoukas, Tel.: +33491041645; fax: +33491041635, email address : vousdoukas@marine.aegean.gr

\begin{abstract}
:
Beach sediment cementation (beachrock formation) is a sedimentary process that can transform significant sections of beaches into rock outcrops. This contribution reports the results of two questionnaire surveys (one focusing on foreign tourists and the other on local people) carried out in coastal resorts of the island of Lesbos (Greece), on the perceptions of beach users regarding the impacts of beachrocks on their recreational activities. The survey focusing on foreign tourists showed that the majority of the interviewees took notice of the formations and commented negatively on them. Although most of the interviewees did not consider beachrocks a significant safety risk, a considerable proportion of the sample stated that beachrocks influenced their beach ratings that they would prefer beachrock-free beaches and would be willing to contribute financially to preventative and protective measures. In contrast, the results of the survey focusing on local people, who are more familiar with the phenomenon, showed a high perception of beachrock-related risks and limited beachrock tolerance. In addition to the safety risks that the irregular, slippery, beachrock surfaces may pose to beach users, beachrocks may also degrade beach aesthetics, promote beach sediment erosion and decrease the beach carrying capacity. As beachrocks are a common attribute of tropical, subtropical and low-temperate beaches that are typically associated with major tourist destinations, and are likely to spread under global warming conditions, they may be considered as a significant threat to the coastal tourist industry.
\end{abstract}

Keywords: Beachrocks; Coastal tourism; Risk perception; Beach safety; Beach carrying capacity; Beach management

\section{Introduction}

Tourism has become a major economic activity in coastal areas (e.g. [Ariza et al., 2008] and [King, 2005]). An important natural asset for its development is the presence of attractive beaches i.e. of lowlying coasts built on sand or pebbles (e.g. Komar, 1998). These dynamic coastal environments, which, in most cases, form only a confined part of the coastline (EUROSION, 2004), are particularly sensitive to environmental conditions and are going to feel the brunt of the environmental impacts of present and predicted climatic changes (Trenberth et al., 2007). Already, most beaches are under erosion, a trend that may considerably affect the growth of coastal 
tourism by limiting beach carrying capacity (EUROSION, 2004). At the same time, beaches may undergo other geological changes, such as the natural cementation of beach sediments by (mainly) precipitated carbonates (Manning \& Lawson, 2002), a sedimentary process which can transform significant sections of the beachface of sandy and pebbly beaches into rock outcrops (beachrocks) (Figure 1).

Beachrock outcrops have been observed in many areas worldwide, reaching lengths of several kilometres, widths of hundreds of meters and thicknesses of more than $2.5 \mathrm{~m}$ (e.g. Vousdoukas, Velegrakis, \& Plomaritis, 2007). The cementation process (see Figure 1c) can be fast (with time scales of the order of few years, e.g. Chivas, Chappell, Polach, Pillans, \& Flood, 1986) and has been linked to physicochemical changes in the interstitial water of the beach sediments that decrease the solubility and promote the precipitation of carbonates (Tucker, 1991) and/or to particular biogeochemical processes (e.g. Neumeier, 1999). Since carbonate precipitation/beachrock formation is favoured by increased temperatures, beachrocks are common occurrences of the tropical, sub-tropical and low temperate coasts (e.g. Vousdoukas, Velegrakis, \& Plomaritis, 2007).

Although the consolidation of beach sediments commences, in most cases, under a thin veneer of unconsolidated sediments in the 'dry' part of the beach, beachrock formations tend to outcrop as a response to wave forcing (e.g. Rey, Rubio, Bernabeu, \& Vilas, 2004). Long-exposed beachrocks show surfaces with irregular relief (Figure lb, d, e and f), exhibiting a multitude of erosional features, such as weathering basins, potholes, broken slabs, transverse to coastline furrows, undercuts, rims and 'scour steps', which may pose significant risks to the safety of beach users (Velegrakis, Vousdoukas, \& Meligonitis, 2005). 
Beaches, apart from being areas for recreational use (Jimenez et al., 2007), also act as natural 'buffer' zones absorbing the wave energy (e.g. Komar, 1998) and as habitats for various shallow water species (Brown, 1982). Hence, from many points of view (e.g. aesthetic, socio-economic and ecological), beaches constitute coastal community assets (Skourtos, Kontogianni, Georgiou, \& Turner, 2005), that require sophisticated management (e.g. see Davidson et al., 2007; Turner \& Anderson, 2007), the main objectives of which should be beach preservation, natural value sustainability and risk-free recreational use.

Beachrock occurrence may be relevant to the above considerations in different ways. Beachrocks have been found to control beach morphodynamics and may promote erosion of beach sediments (e.g. see Cooper, 1991); thus, they can affect the actual size of a beach and diminish its carrying capacity (Manning \& Lawson, 2002). Moreover, the presence of weathered/deformed beachrock outcrops at the beachface, commonly colonised by assemblages of epilithic and borrowing organisms (Brattström, 1992) that form a 'slippery' mat, can make the access to the sea difficult, or even dangerous, and degrade the aesthetics and amenity value of the beach and, thus, affect its touristic potential

Despite the potentially undesirable consequences of beachrock formation/outcropping on the recreational use and touristic potential of beaches, as well as the high incidence of beachrocks at a global scale (Vousdoukas, Velegrakis, \& Plomaritis, 2007), no relevant specific studies have so far been carried out. The objective of the present contribution is to report the results of a survey, undertaken in two resort beaches on the island of Lesbos (Greece, E. Mediterranean), designed to help identify the perceptions of beach users regarding the effects and safety risks associated with beachrock occurrence. 


\section{Study area}

The survey was carried out at Plomari and Vatera beaches (Lesbos, NE Aegean Sea, Greece). Beachrock formation has been quite active along the Mediterranean coasts (Vousdoukas, Velegrakis, Kontoyianni, Makrykosta, \& Eleftheriou, 2007), which host $\sim 30 \%$ of the globally-reported beachrock occurrences (probably due to increased summer temperatures), with Greece being amongst the countries with the highest ratios of reported beachrock occurrences per coastline length (for further details, see Vousdoukas, Velegrakis, \& Plomaritis, 2007).

The economy of the island of Lesbos (area of $\sim 1,630 \mathrm{~km}^{2}$ and population of 90,000) (GSNSS of Greece, 2006) is based mainly on agriculture (with olive oil as the main product), food product manufacture (e.g. Lesbos is the main producer of the Greek aperitif 'ouzo'), fisheries and, to a lesser extent, tourism. The two survey areas are amongst the most touristically developed of the island, while their beaches are partially occupied by beachrock outcrops (around $\sim 1 / 3$ of their total beach length). In general, both beaches may be considered as 'mild cases' of beachrock outcropping, as both the length and the width of the exposed formations are relatively confined. The partial beachrock coverage of the beach has been an important criterion in the selection of the survey sites, since differences between the beachrock-free and the beachrock-occupied sections of the beach can be highlighted.

Vatera Beach is the longest beach of the island $(\sim 7.5 \mathrm{~km})$ and comprises a coastal resort, mainly inhabited during the summer by Greek visitors and foreign tourists (mainly from northern Europe). In addition to a substantial number of summer residences (mostly owned/used by Greeks), there are 4 hotels (with a capacity of 320 beds), as well as several smaller guesthouses, resulting in a total capacity of $\sim 1,600$ beds during the summer period (Lesbos Union of Hotel Owners, pers. comm.). 
Similarly, Plomari Beach, which is located in the vicinity of the town of Plomari (population 3,500), has 5 hotels and several guesthouses with a total capacity of around 1,200 beds (Lesbos Union of Hotel Owners, pers. comm).

\section{The survey}

Questionnaire surveying has been commonly used to provide an insight into people's perceptions/attitudes and several such studies have taken place in connection with coastal zone management (e.g. Chaniotis \& Stead, 2007), tourism (e.g. Eitzingera \& Wiedemann, 2007) and risk assessment (e.g. Kontogianni \& Skourtos, 2007). The surveys carried out for the purposes of the present study aimed to (a) collect detailed information on the profile of foreign tourists and their 'unbiased' perception of beachrocks (as the majority of this constituency was not expected to be aware of the phenomenon) and (b) provide an insight into the attitudes of the 'local'

people (owners/users of summer residences), who have longstanding experience of the phenomenon and are familiar with its effects. Given the different nature of the two samples, two different survey-questionnaires were prepared. During both surveys, the questionnaires were completed with the help of specially-trained interviewers.

The survey focusing on foreign tourists took place in two phases. In July 2004, 50 foreign tourists were interviewed in person at the beach of Vatera, whereas, in August 2005, 106 foreign tourists participated in the survey which took place in both Vatera and Plomari beaches. The questionnaire used was based on the Contingent Valuation Method (CVM, e.g. Bishop \& Heberlein, 1979; Ciriacy-Wantrup, 1952; Mitchell \& Carson, 1989), and accompanied by visual material giving further examples of beachrock formations. It consisted of 6 sections: (i) interviewee's profile and his/her activities on the beach and while on holidays; (ii) risk perception 
assessment; (iii) perceptions of beachrocks and their impacts (including questions regarding the willingness to pay for the mitigation of the phenomenon and its impacts); (iv) attitudes towards the environment; (v) attitudes towards life; and (vi) socio-demographic information. The questionnaire used in the 'local' people survey (July 2004) was much shorter, consisting mainly of questions regarding beachrocks and their possible effects on beach usage, as well as a few questions aimed at identifying broadly the profile of the interviewee. During this survey, the interviews were conducted at the beach houses owned/used by the questioned people, with the interviewers visiting 52 such residences.

Quality control of the collected information showed that all questionnaires were suitable for further analysis and comparison between the results of the two phases of the foreign tourist surveys showed no significant differences.

The results were analyzed using the SPSS statistical software package; the methods used for the analysis varied depending on the nature of the variables. As most of the studied variables were characterised by discrete values (e.g. integers 1-5), non-parametric tests were used (Kruskal \& Wallis, 1952), following control of the validity of the method's assumptions. Differences in perceptions (regarding e.g. beach quality or the significance of an issue) between groups qualified by different criteria (including e.g. age, gender, income) were investigated through Pearson Chi-square tests (e.g. see Norusis, 2002). Finally, in the case of continuous variables, t-tests were used to examine the significance of differences between pairs, as well as One-Way ANOVA tests, when the criteria regarding the homogeneity of variance and normality were satisfied. In all these tests, the rejection of the null hypothesis meant that there was a significant difference between the groups (for further details, see Norusis, 2002). 


\section{Results}

\subsection{Sample profile}

The total sample consisted of (a) randomly chosen foreign tourists from those present on the Vatera and Plomari beaches during the surveys and (b) Greek owners/users of Vatera summer residences. In both cases, persons from both sexes and several age groups (18-63 years) participated in the survey, with the number of representatives from each sex and age group being reasonably balanced.

The age of most foreign tourists was between 30 and 50 years, while the most dominant income class was found to be the highest ( $26 \%$ of the foreign visitors declared an annual income in excess of $75 \mathrm{k} €$ ) (Table 1). Most of the interviewees ( $70 \%)$ were visiting Greece for one or two weeks, which is the typical duration of the charter-flight vacation packages. The majority of the survey participants (more than $60 \%$ ) were living in coastal areas, $\sim 70 \%$ were married and $\sim 65 \%$ of them declared that they own a house or a flat. More than half of the interviewees $(\sim 56 \%)$ were in full-time employment, whereas $\sim 17 \%$ were students. The survey also showed that a large percentage of the foreign tourists had a high level of education, with more than $45 \%$ possessing a BSc or equivalent degree and $22 \%$ a postgraduate degree (MSc and/or $\mathrm{PhD}$ ) (Table 1). Finally, less than $20 \%$ of the survey participants declared that they were involved in environmental activities/organizations.

Attractive and calm beaches with warm and clean waters are one of the major attractions of the Greek islands as a holiday destination, and in Lesbos, due to the lack of significant archaeological sites, tourism is focused on beach recreational activities. As services related to water sports/diving are not widespread on the island, most of the interviewees declared that they were spending most of their time in relaxed leisure 
activities in the vicinity of the beach (e.g. swimming/sunbathing, walking, enjoying the scenery etc, see Figure 2a). The most valued feature of the beach was found to be its perceived cleanliness (Figure 2b), which was considered far more important than its other features (e.g. scenery, morphology and infrastructure). In terms of water quality, the cleanliness/clarity of the water was considered by far the most significant attribute (Figure 2c); on both surveyed beaches, the water quality was considered exceptional by more than $50 \%$ of the interviewees. In addition, more than $50 \%$ of the interviewees described the beach as good or very good, a percentage that increased to $\sim 70 \%$ for the beachrock-free sections of the beach (Figure 3).

Significant differences were found for the water quality criteria and ratings between survey participants from northern and southern European countries (Pearson Chi-Square $=11.09$, degress of freedom $(d f)=3$, probability, under the null hypothesis $(p)=0.011)$. The former were shown to judge water quality on the grounds of water cleanliness and were more satisfied by the water quality (Kruskal-Wallis Chi Square $=3.731, d f=1, p=0.043)$. Moreover, younger people and women were found to be slightly more satisfied by the quality of the beach (Kruskal-Wallis Chi Square= 3.341 and $4.111, d f=1, p=0.039$ and 0.0499 respectively). No other significant differences were found regarding quality criteria, ratings and activities amongst groups defined by age, gender, marital status, education, income, etc.

Since one of the aims of the study was to investigate the perception of beachrock-induced risk, information regarding risk perception in general was deemed useful; this was obtained by questions contained in a specific part of the questionnaire. According to the responses, smoking and driving were viewed as the two most prominent risks, whilst, for example, terrorist activities and HIV-infection were considered as low risks, as was swimming in the presence of beachrocks (Table 
2). Environment-friendly attitudes which, however, were also rather pessimistic and showing alarm ('the earth has only limited room and resources...' and 'the natural balance is very delicate and can be easily upset...'), prevailed in comparison to more anthropocentric positions. Finally, the majority of the interviewees were found to perceive life from an 'individualistic' standpoint, declaring that they regarded themselves as responsible for their own positions and actions.,

\subsection{Beachrock perception}

With regard to the survey focusing on the foreign tourists, the results showed that, although $83 \%$ of the interviewees had not seen beachrocks before (an expected outcome, as the large majority originated from northern European countries, where beachrocks are extremely rare (see Vousdoukas, Velegrakis, \& Plomaritis, 2007), $\sim 70 \%$ took notice of beachrocks (particularly the women) and were annoyed by their presence (Figure 4a, b). When the survey participants were asked to rate the quality of the beach, 30\% acknowledged beachrocks as a factor influencing their rating. However, the overall beach quality ratings were still high, probably due to the fact that the main criterion influencing beach rating was the cleanliness of beach and water, which was perceived as good or very good in both survey sites.

During the survey, participants were found situated in different sections of the beach, some of which with and others without beachrock outcrops. It is interesting to note that beach quality ratings varied, depending on the presence of beachrocks at the location of the interviewee. The responses shifted towards higher ratings for the beachrock-free parts at the top-end of the rating spectrum (see Figure 3); the difference was statistically significant (Kruskal-Wallis Chi Square $=7.943, d f=1, p=$ 0.005). Furthermore, when asked, $\sim 37 \%$ of the interviewees, found to be located in 
beachrock-infected sections of the beach stated that they would prefer the beach without these formations.

In general, the majority of the survey's foreign participants considered beachrocks as a problem of medium significance, presenting a low safety risk (see Table 2). Nevertheless, $\sim 64 \%$ of them stated that the local/national authorities (and the EC) should take measures to protect beach users from accidents associated with beachrocks (e.g. injuries caused by slipping on them), and around 50\% suggested that measures should be taken to prevent further beachrock encroachment. Survey participants over 40 years of age were found to be more more sensitive towards beachrock-induced risks. There was a statistically significant higher demand for preventative measures (Pearson Chi Square $=4.35, d f=1, p=0.033$ ) as well as higher ratings regarding the importance of the problem and the perceived risk (Kruskal-Wallis Chi Square $=4.122$ and 5.679, $d f=1, p=0.042$ and 0.017, respectively).

It is interesting to note that $\sim 45 \%$ of the survey participants were willing to contribute financially to actions (and research) focusing on the mitigation of the negative impacts of beachrock; the average sum survey participants were prepared to contribute was $\sim 15 €$ per person per year. Normalisation of the offered amount of financial contribution with regard to the income class showed that there were significantly higher contributions offered by survey participants in the lower income groups $(<20000 €$, see also Table 3$)$.

Female participants clearly showed a more discerning attitude, identifying more clearly the problem and appearing keener to assist in remediation activities. Women in the survey groups considered as more urgent the need (a) to protect swimmers (Pearson Chi Square $=5.384, d f=1, p=0.021$ ) and (b) to take measures 
to prevent further beachrock encroachment (Pearson Chi Square $=4.989, d f=1, p=$ 0.025). The mean financial contribution offered by women was found to be $\sim 29 €$ per year as compared to $9 €$ for men, a statistically significant difference $(t=-2.758, p=$ 0.007, see also Table 4). This may be explained by the fact that more female interviewees took notice of the formations and identified them as a potential safety risk compared to the male interviewees, despite the fact that fewer women declared that they had previously encountered the phenomenon.

Survey participants involved in environmental activities/organizations were found to be more willing to contribute (with an average of $\sim 23 €$ ) than the rest of the interviewees, a difference, though, that was not statistically significant. There was no evidence that marital status or education level influenced attitudes towards beachrocks. Finally, comparison between a 'risk perception index', indicating each person's tendency towards perceiving risks (established on the basis of the mean value of the responses obtained in the risk perception section of the questionnaire (1very low to 5-very high)) and beachrock risk perception showed poor correlation.

As mentioned earlier, a separate questionnaire survey took place in Vatera beach in July 2004 to provide information on the attitudes of the 'local' people towards the beachrocks. The relevant questionnaire was shorter than that designed for the foreign tourists and focused on the perceived effects of beachrocks. The results make interesting reading, since they were quite different from those of the foreign tourist survey. $50 \%$ of the 'local' interviewees declared that they were experiencing difficulties accessing the sea due to beachrocks and $\sim 25 \%$ declared that they had had one or more accidents from slipping on beachrocks (Figure 5a, b). Given that the 'local' survey population were mostly owners of summer residences in Vatera they were, expected to be positively biased towards the survey area. Nevertheless, more 
than $25 \%$ of the relevant interviewees regarded beachrocks as "a reason to avoid the beach"; importantly, this percentage almost doubled in a scenario of further beachrock propagation/outcropping (Figure 5c, d). These results indicate more clearly the potential impact of beachrock presence/outcropping on the beach recreational use/value than those reflected in the answers of the (less seasoned) foreign users.

\section{Discussion}

One of the most significant implications of beachrocks is related to the safety of beach users, which is regarded as one of the major concerns of coastal management schemes (e.g. Jimenez et al., 2007). The nearshore zone is a dangerous area (Short \& Hogan, 1994), due to rapidly changing bathymetry, breaking waves, the presence of various nearshore currents and the high concentration of beach visitors/users which enhances risks by stressing the existing safety infrastructure. The presence of weathered/eroded beachrock outcrops with highly irregular relief, which are also veneered by slippery mats of biological origin (see Figures 1 and 6) at the high energy swash and surf zones may significantly increase the risks of accidents and injuries for beach users.

Against this background, the results of the present study are of some interest. The foreign tourist survey has highlighted that, although beachrock outcrops were not identified as a rapidly evolving phenomenon, nor were the associated risks to beach users adequately appreciated, beachrocks were noticed, even by tourists that had no prior experience/knowledge of them. It must be noted here, that both survey areas can be characterised as 'mild' cases in terms of beachrock presence, as beachrocks (at least outcrops) are found along limited sections of the beach. Since the users of those beaches are presented with alternatives i.e. to settle in beachrock-free sections of the 
beach, where access to the sea is not hampered by the formations, their awareness of the beachrock-related nuisance and risks may be relatively low. However, it was found that the beachrock presence, even in a 'mild' form, may constrain the recreational use of the beach; this is indicated by the surprising high percentage of the foreign beach users $(\sim 45 \%)$ who were willing to contribute financially to protective and preventative measures, even though they did not perceive the phenomenon as a high risk.

The results of the questionnaire survey of the 'locals' i.e. of the Greek owners/users of the summer residences of Vatera were quite different (see Figure 5), as they showed (a) a considerably higher perception of beachrock-related risks and (b) a beachrock tolerance constrained by the formations' spatial extent. It appears that longstanding experience with the phenomenon has revealed the associated risks more clearly to this constituency. At this point it is interesting to note that evidence from other beaches, where the phenomenon is more widespread, has shown a higher incidence of beachrock-related accidents (Velegrakis et al., 2005) than that revealed in the present study. The dangers imposed by the presence of beachrock outcrops are also shown by the 'unusual' measures employed by local authorities and/or beach hotel owners in areas with widespread beachrock exposure, such as the excavation of corridors through the formations (Figure 6d, e), or the placement of rubber mats upon the outcrops (Figure 6h, i) to facilitate safe passage into and out of the sea.

The results of the present study provide some insight into perceptions of beach users, in particular regarding the safety, aesthetics and recreational value of beaches affected by beachrocks. However, they should be also considered in a broader context. 
Beachcrops can considerably affect beach morphology and dynamics by: (i) 'locking' the beach profile; (ii) modifying the nearshore hydrodynamics; (iii) changing the porosity of beach sediments and, thus, their response to wave forcing; and (iv) creating 'scour steps' (see Figure 1b) at the offshore margins of the formations that can alter significantly the long-and, particularly, the cross-shore sediment transport (Vousdoukas, Velegrakis, \& Plomaritis, 2007). The joint, longterm, effect of the above processes is likely to be net beach sediment loss/beach erosion (see Figure $6 \mathrm{a}, \mathrm{b}, \mathrm{d}$, e and $\mathrm{f}$ ) and outcropping of beachrocks, the majority of which have been initially formed under a veneer of unconsolidated sediments (Vousdoukas, Velegrakis, \& Karambas, 2007). Therefore, in addition to posing safety risks to beach users, beachrock formation/outcropping can promote beach sediment erosion, which is currently identified as one of the major problems faced by coastal communities (EUROSION, 2004). Moreover, the phenomenon can affect negatively the economic potential and value of a beach by decreasing its 'carrying capacity' i.e. the number of visitors and kind of activities that can be accommodated on a specific beach in a sustainable way; beachrock outcrops may (a) reduce the functional area of the beach (see Figure 6) and (b) require lower concentrations of beach users in order not to overwhelm the available safety infrastructure.

At the same time, it should be noted that beachrock outcrops may, in some cases, also have some positive effects in terms of coastal preservation, particularly along coastlines threatened by severe erosion due to sea level rise, like the Pacific ocean atolls (Dickinson, 1999). Relict (submerged) beachrocks located in the nearshore waters can act as submerged barriers, promoting offshore wave dissipation/ breaking and, thus, decreasing the wave energy impinging on the coast (e.g. Gionis, Poulos, Mpouziotopoulou, \& Ntounas, 2004). Moreover, more recent beachrocks lying on the 
inner surf and swash zones may armour the beach and prevent shoreline retreat; this effect may be significant when coastline preservation is a primary consideration (Dickinson, 1999). Beachrock formation/outcropping may also result in increased biodiversity in the coastal zone, since beachrock outcrops can create habitats suitable for colonisation by hard-substrate species (e.g. corals, molluscs, algae and annelid worms) (Brattström, 1992; Vousdoukas, Velegrakis, \& Plomaritis, 2007). However, it is questionable whether the overall effect on the coastal ecology would be beneficial, particularly in view of the biodiversity losses in soft-substrate species (Brown, 1982).

Beach aesthetics/scenery may suffer by the presence of beachrocks, as beachrock-infected beaches do not comply with the widely-recognisable beach model (long and wide beaches consisting of light coloured sands). Beaches fronted by darkcoloured rock formations, which are veneered by slippery algal mats (e.g. Brattström, 1992; Vousdoukas, Velegrakis, \& Plomaritis, 2007), are unlikely to comply with this model (see Figures 1 and 6). It is very revealing that beachrock-occupied beaches rarely feature in the visual material used in promotional publications and advertisements directed at tourists, in spite of their widespread occurrence in most of the popular holiday resort destinations (i.e. the Mediterranean and the Caribbean coasts and the Pacific and Indian Ocean coasts, see Figure 7).

In this context, it should be recalled that coastal tourism, which depends on the good state of the beaches, has increasingly become an important wealth generator (e.g. European Commission for Fisheries and Maritime Affairs, 2006). For example, a crude estimation for Greece (based on the annual proceedings from foreign tourism, the proportion of tourists visiting coastal resorts compared to those visiting inland destinations (e.g. EUROSION, 2004) and the overall length of the Greek beaches) 
has shown that beaches are particularly important for the Greek economy, generating on average at least $1300 €$ per year/ per m length (Velegrakis et al., 2005).

Therefore, since beachrock formation/outcropping introduces safety risks, diminishes the carrying capacity and negatively affects the aesthetics and recreational potential of beaches, it may be considered as a significant threat to the development of tourism and economy of the coastal areas.

Beachrock formation is particularly common in the warm and low-temperate coasts (Figure 7), a fact that can be attributed to the increase of carbonate cement precipitation with increasing temperature (e.g. see Bathurst, 1975; Milliman, 1974). As a result, it is not unlikely that beachrock formation will accelerate in the future (and also spread out to areas where it is presently rare) in response to the current global warming conditions (Trenberth et al., 2007). Presently, more than 300 occurrences have been reported in the widely-available scientific literature, which, however, are likely to form only a small proportion of the actual (unreported) number. Most of these occurrences are found along coastal areas with economies, more or less, dependent on tourism. Consequently, it is important for coastal managers and stakeholders to be aware of the phenomenon, in order to identify, monitor and evaluate its effects and consider the appropriate measures to ameliorate its impacts; thus, it should be considered in the development of management plans for the sustainable coastal development.

\section{Conclusions}

The present study has highlighted, for the first time, the negative effects of beachrocks formation/outcropping to the recreational use and amenity value of beaches. With regard to a foreign tourist questionnaire survey (Vatera and Plomari 
beaches, Lesbos), even though the vast majority of the interviewees declared that it was their first encounter with beachrocks, they, nevertheless, took notice of them and their potential negative effects. Moreover, although the majority of the interviewees did not consider the beachrock-induced safety risks as significant, considerable sections of the survey participants (more than 35\%) stated that the beachrock presence influenced their beach quality ratings, that they would definitely prefer beachrock-free beaches and that they were willing to contribute financially for protective and preventative measures. In comparison, the results of the survey of 'local' people (Vatera, Lesbos), who were more familiar with the phenomenon, showed a high perception of beachrock-related safety risks and limited beachrock tolerance. It appears that beach users regard beachrock formation/outcropping as an undesirable beach attribute that can limit their recreational activities.

In addition to the safety risks that irregular beachrock surfaces, covered with slippery biological mats, can pose to beach users, beachrocks can also promote beach sediment erosion, thus adversely, affecting the beach carrying capacity, and beach aesthetics. As beachrock formation/outcropping is a common phenomenon of the tropical, subtropical and low temperate coasts, which are also major tourist destinations and is likely to spread under global warming conditions, it may be considered as a threat to coastal zone development, requiring urgent attention.

\section{References}

Ariza, E., Jiménez, J. A., \& Sardá, R. (2008). A critical assessment of beach management on the Catalan coast. Ocean \& Coastal Management, 51(2), 141-160.

Bathurst, R. G. C. (1975). Carbonate Sediments and their Diagenesis (Vol. 12): Elsevier Publishing Co.

Bishop, R. C., \& Heberlein, T. A. (1979). Measuring values of extra-market goods: are indirect measures biased? American Journal of Agricultural Economics, 61, 926930. 
Brattström, H. (1992). Marine biological investigations in the Bahamas. 22. Littoral zonation at three Bahamian beachrock localities. Sarsia 77, 81-109.

Brown, B. (1982). Spatial and temporal distribution of a deposit-feeding polychaete on a heterogeneous tidal flat. Journal of Experimental Marine Biology and Ecology, 65(3), 213-227.

Chaniotis, P., \& Stead, S. (2007). Interviewing people about the coast on the coast: Appraising the wider adoption of ICZM in North East England. Marine Policy, doi:10.1016/j.marpol.2006.12.005.

Chivas, A., Chappell, J., Polach, H., Pillans, B., \& Flood, P. (1986). Radiocarbon evidence for the timing and rate of island development, beach-rock formation and phosphatization at Lady Elliot Island, Queensland, Australia. Marine Geology, 69, 273-287.

Ciriacy-Wantrup, S. V. (1952). Resource conservation: Economics and Policies. Berkeley. CA: University of California Press.

Cooper, J. A. G. (1991). Beachrock formation in low latitudes: implications for coastal evolutionary models. Marine Geology, 98(1), 145-154.

Davidson, M., Van Koningsveld, M., de Kruif, A., Rawson, J., Holman, R., Lamberti, A., et al. (2007). The CoastView project: Developing video-derived Coastal State Indicators in support of coastal zone management. Coastal Engineering, 54(6-7), 463475.

Dickinson, W. R. (1999). Holocene Sea-Level record on Funafuti and Potential impact of global warming on Central Pacific Atolls. Quaternary Research, 51, 124132.

Eitzingera, C., \& Wiedemann, P. (2007). Risk perceptions in the alpine tourist destination Tyrol-An exploratory analysis of residents' views. Tourism management, 28, 911-916.

European Commission for Fisheries and Maritime Affairs. (2006). Towards a future Maritime Policy for the Union: A European vision for the oceans and seas. Luxembourg: European Communities.

EUROSION. (2004). Living with coastal erosion in Europe: Sediment and Space for Sustainability. PART I. Final Report of the Project 'Coastal erosion'- Evaluation of the need for action: Directorate General Environment, European Commission.

Gionis, G., Poulos, S., Mpouziotopoulou, N., \& Ntounas, K. (2004). The effect of a natural submerged breakwater on the hydrodynamic and sedimentological conditions on Amoudaras beach (North coasts of Herakleion prefecture, Crete). Paper presented at the 10th International Conference of the Greek Geological Society, Thessaloniki.

GSNSS of Greece. (2006). General Secretariat of the National Statistical Service of Greece, , from http://www.statistics.gr

Jimenez, J. A., Osorio, A., Marino-Tapia, I., Davidson, M., Medina, R., Kroon, A., et al. (2007). Beach recreation planning using video-derived coastal state indicators. Coastal Engineering, 54(6-7), 507-521.

King, B. (2005). Pacific island tourism. Tourism Management, 26(4), 632-633.

Komar, P. D. (1998). Beach Processes and Sedimentation (2nd ed.). N.J., USA: Prentice Hall.

Kontogianni, A., \& Skourtos, M. (2007). Social Perception of Risk informing Integrated Coastal Zone Management on accidental oil - spill pollution: ' the reason you pollute matters, not numbers'. In R. Krishnamoorthy (Ed.), Integrated Coastal Zone Management - Present Global Scenario: New India Publishing Agency.

Kruskal, W. H., \& Wallis, W. A. (1952). Use of ranks in one-criterion variance analysis. Journal of the American Statistical Association, 47 (260), 583-621. 
Manning, R., \& Lawson, S. (2002). Carrying Capacity as "Informed Judgement": The Values of Science and the Science of Values. Environmental Management, 30, 157168.

Milliman, J. D. (1974). Marine Carbonates. Berlin: Springer-Verlag.

Mitchell, R. C., \& Carson, R. T. (1989). Using Surveys to Value Public Goods: The Contingent Valuation Method: RFF Press.

Neumeier, U. (1999). Experimental modelling of beachrock cementation under microbial influence. Sedimentary Geology, 126(1-4), 35-46.

Norusis, M. J. (2002). SPSS 11.0 Guide to Data Analysis: Prentice Hall.

Rey, D., Rubio, B., Bernabeu, A. M., \& Vilas, F. (2004). Formation, exposure, and evolution of a high-latitude beachrock in the intertidal zone of the Corrubedo complex (Ria de Arousa, Galicia, NW Spain). Sedimentary Geology, 169(1-2), 93-105.

Short, A. D., \& Hogan, C. L. (1994). Rip currents and beach hazards: their impact on public safety and implications for coastal management. Journal of Coastal Research, 12, 197-209.

Skourtos, M., Kontogianni, A., Georgiou, S., \& Turner, R. K. (2005). Valuing Coastal Systems. In R. K. Turner, W. Salomons \& J. Vermaat (Eds.), Managing European Coasts: Past, Present and Future (pp. 119-136): Springer Verlag.

Trenberth, K. E., Jones, P. D., Ambenje, P., Bojariu, R., Easterling, D., Klein Tank, A., et al. (2007). Observations: Surface and Atmospheric Climate Change. In S. Solomon, D. M. Qin, M. , Z. M. Chen, M. , K. B. Averyt, M. Tignor \& H. L. Miller (Eds.), Climate Change 2007: The Physical Science Basis. Contribution of Working Group I to the Fourth Assessment Report of the Intergovernmental Panel on Climate Change. Cambridge, United Kingdom and New York, NY, USA.: Cambridge University Press.

Tucker, M. E. (1991). An introduction to the origin of sedimentary rocks. In Sedimentary Petrology (2nd ed., pp. 260): Blackwell Publishing Limited.

Turner, I. L., \& Anderson, D. J. (2007). Web-based and 'real-time' beach management system. Coastal Engineering, 54(6-7), 555-565.

Velegrakis, A. F., Vousdoukas, M., \& Meligonitis, R. (2005). Erosion of Islandic beaches: phenomenology and causes of the degradation of the largest natural resource of isclandic Greece. In G. Tsaltas (Ed.), Islandic Greece in the 21st century (in Greek) (pp. 243-262). Athens: SIDERIS Publications.

Vousdoukas, M. I., Velegrakis, A. F., \& Karambas, T. V. (2007). Morphology and sedimentology of a microtidal, beachrock-infected beach: Vatera Beach, Lesvos, NE Mediterranean. Continental Shelf Research(submitted).

Vousdoukas, M. I., Velegrakis, A. F., Kontoyianni, A., Makrykosta, E., \& Eleftheriou, A. (2007, 9-13 April 2007). Beachrocks in the Mediterranean: Morphodynamic, ecological and socio-economic impacts. Paper presented at the 38th CIESM Congress, Istanbul, Turkey.

Vousdoukas, M. I., Velegrakis, A. F., \& Plomaritis, T. A. (2007). Beachrock occurrence, characteristics, formation mechanisms and impacts. Earth-Science Reviews, 85, 23-46. 


\section{FIGURE CAPTIONS}

Figure 1. (a) Beachrocks (black arrows), occupying the whole length of the beachface of the Super Paradise beach (Mykonos, Greece). (b) Underwater image from Vatera beach (Lesbos, Greece), showing a scour step at the offshore margin of the beachrock outcrop. (c) Scanning Electron Microscope (SEM) image of a beachrock (courtesy I. Issaris), showing the cementing carbonate material surrounding the original beach sediment grains. (d) Long-exposed beachrock (Baracoa, Cuba), exhibiting features of chemical weathering and mechanical erosion, such as dissolution basins and potholes. (e) Exposed beachrock bands at Plomari beach (Lesbos, Greece), showing evidence of intensive mechanical strain (broken slabs). (f) Weathered/eroded beachrock outcrops of a Chalkidiki beach (Greece).

Figure 2. Foreign tourist questionnaire results regarding (a) activities during the vacations, (b) criteria for beach quality rating and (c) criteria for water quality rating.

Figure 3. Beach rating results for the beachrock-infected (black bars) and the beachrock-free (grey bars) sections of the beaches. Note the large increase in the 'very good' rating class for the beachrock-free sections of the beach.

Figure 4. Survey results regarding (a) detection of beachrocks in the particular beach, (b) prior awareness of the phenomenon, (c) perceived need for taking measures to protect the beach users, and (d) perceived need for taking measures to prevent beachrock formation/further propagation .

Figure 5. Greek visitor questionnaire results regarding (a) the difficulty to access the sea due to beachrocks, (b) experience of accidents due to beachrocks, (c) beach rating in the current state of beachrock presence/outcropping and (d) beach rating in the case of further beachrock encroachment.

Figure 6. (a) and (b) Kalafatis beach (Mykonos, Greece), which has experienced significant beach recession in recent years (shown by the relative position of the small pier), due to beachrock/wave interaction (see text); arrows show the offshore margins of the outcrops. (c) S. Rhodes (Greece), where the whole beach has 'turned into stone'; (d) beachrock outcrops at Chrysopigi (Sifnos, Greece) in 2001, occupying most of the beach and characterised by colonising biological assemblage zonation (small arrows); (e) the same beach in 2005, when a corridor (black arrow) was excavated into the beachrock outcrop to facilitate the access to the sea; (f) the combination of beachrock occurrence and the seawall has diminished the beach of Platy Gialos (Sifnos) to an insignificant width; (g) beachrocks at Barceloneta beach (Barcelona, Spain), where a significant investment has taken place for the creation/preservation of an artificial beach and, consequently, beachrock outcropping is undesirable and tortuous; and (h) and (i) plastic mats placed upon the beachrock surface to facilitate the access to the sea, which has become dangerous due to the slippery layer of algae found on the beachrock surface (Mykonos, Greece).

Figure 7. World map of the reported beachrock formations. The phenomenon is of global range, thriving mainly along warm coasts, like those of the Caribbean and Mediterranean Seas and the Pacific and Indian Ocean (for more detailed information, see Vousdoukas, Velegrakis, \& Plomaritis, 2007). 
Table 1. Survey results showing the general profile of the sample of the foreign interviewees, in terms of gender, age, income (in x $10 \mathrm{k} €$ ), marital status, education level and occupation.

Table 2. Results related to some of the questions regarding perceived risks (values as percentages of the total)

Table 3. (Upper) The mean of the financial contributions the participants are willing to contribute for beachrock research (for each income group), divided by the income of the group (in $\mathrm{k} €$ ). (Lower) One-way ANOVA results for the comparison of the means between income groups.

Table 4. (Upper) The mean of the financial contributions the participants are willing to offer for research on beachrocks, raw or divided by the income group ( $€ \times 1000$ ) for each gender; (Lower) One way ANOVA results for the comparison of the means between genders. 

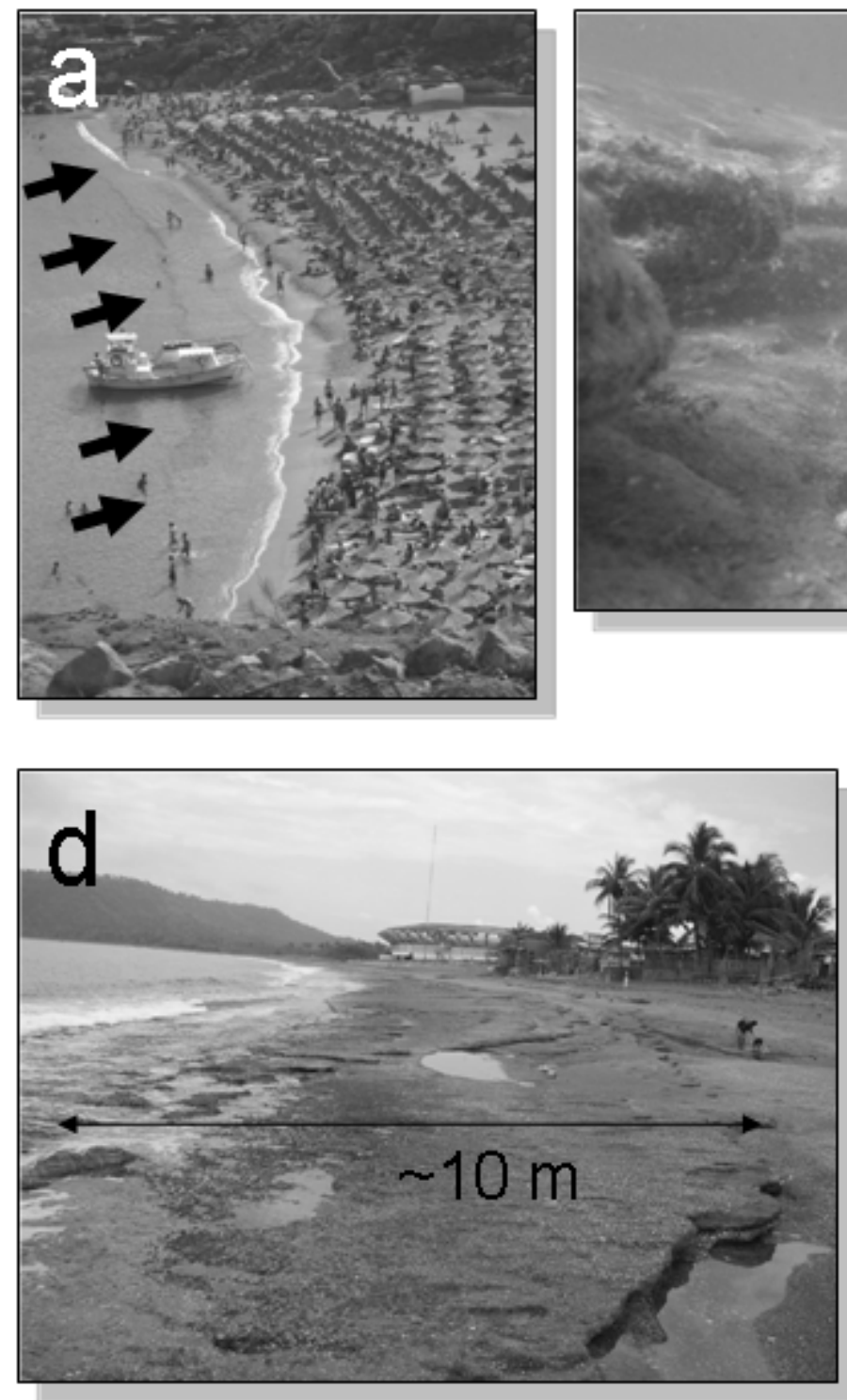

\section{e}

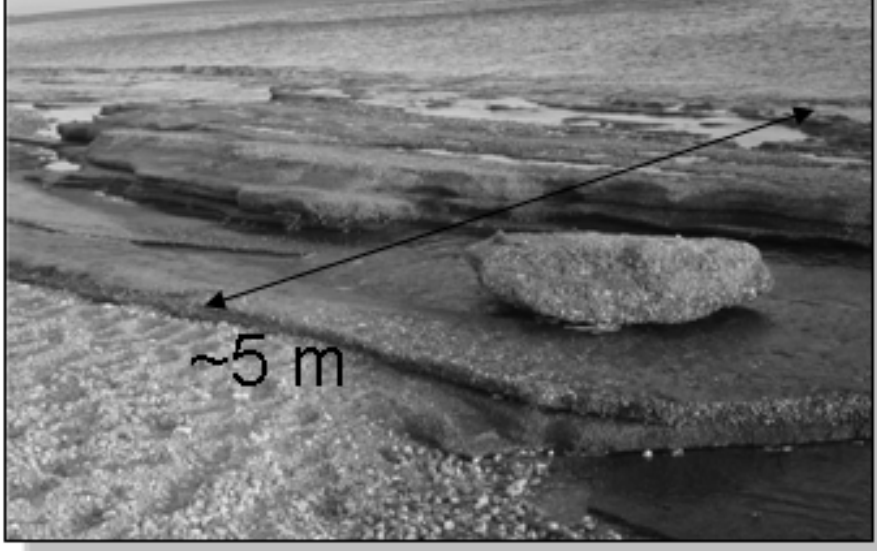

b $c$ cement

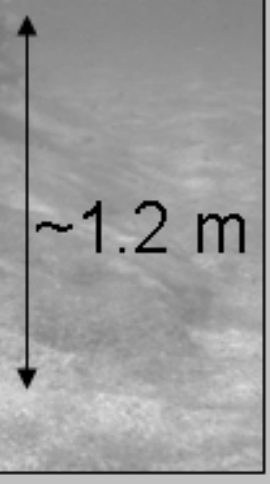

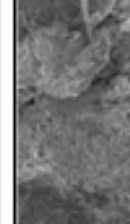

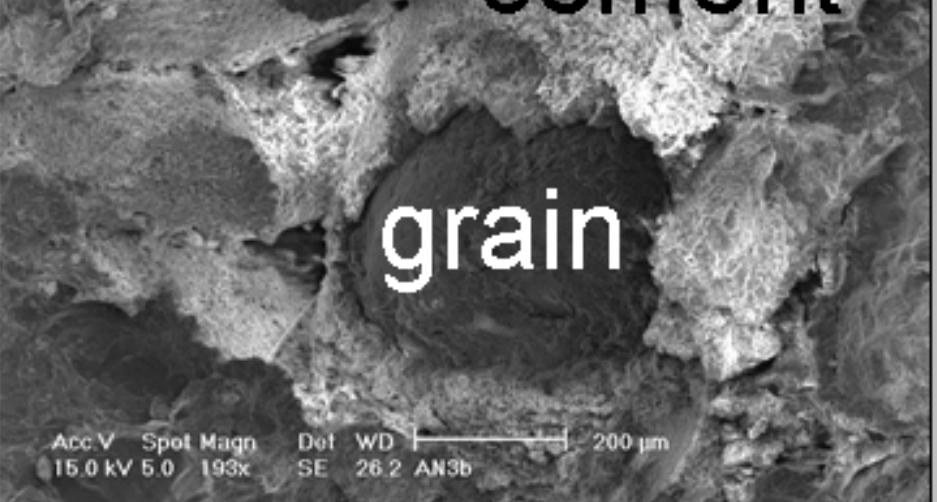

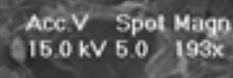

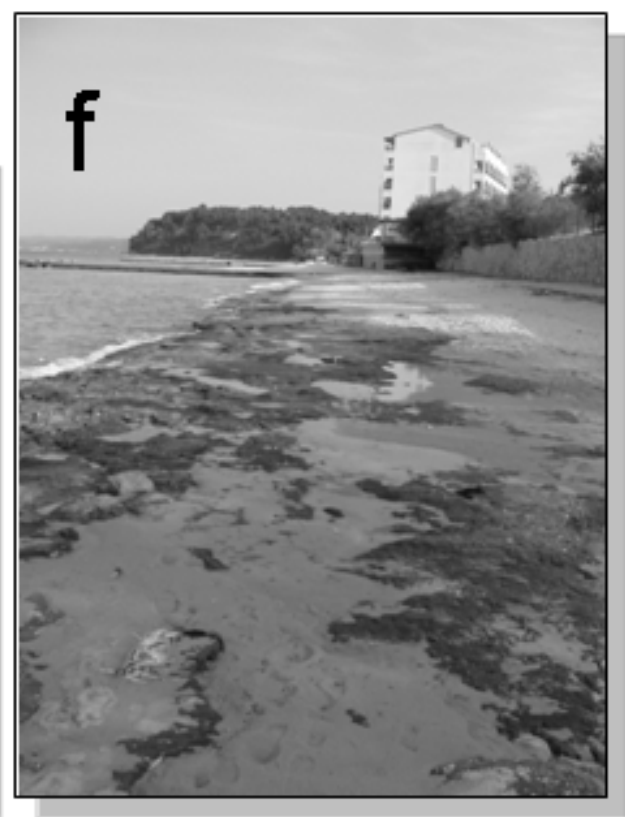


a Activities on vacations

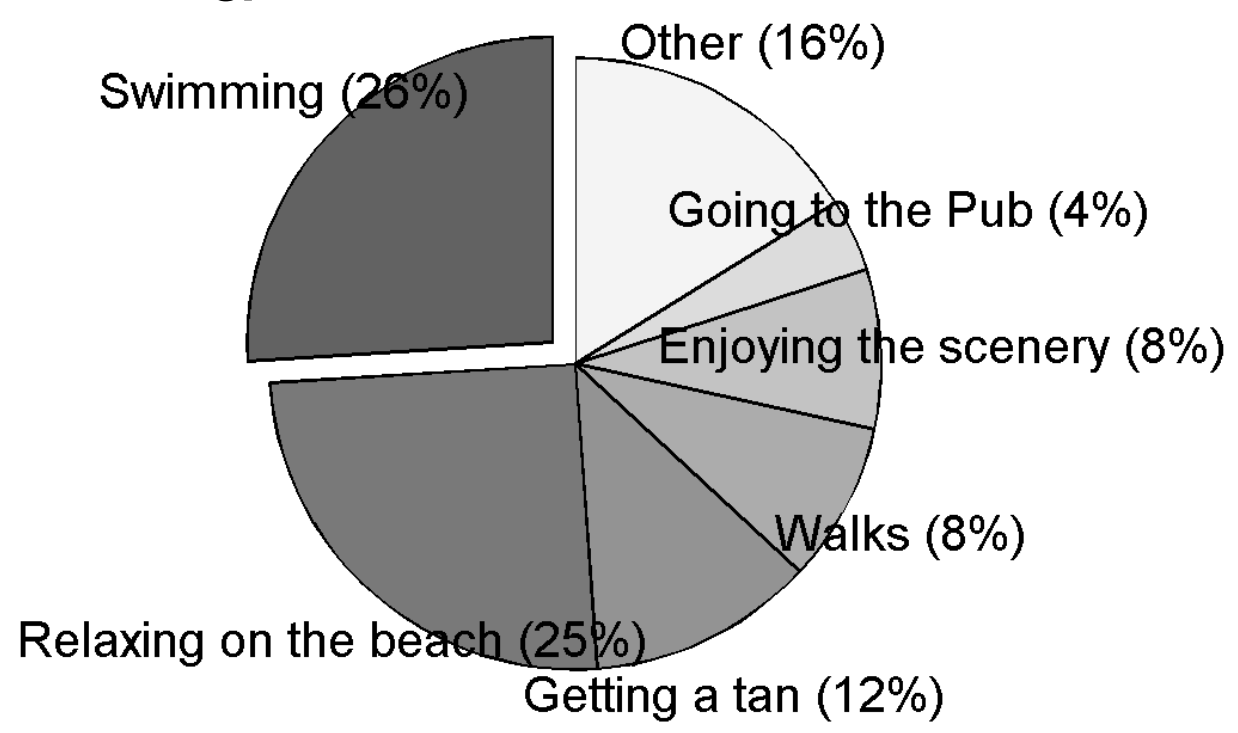

b Beach quality criteria

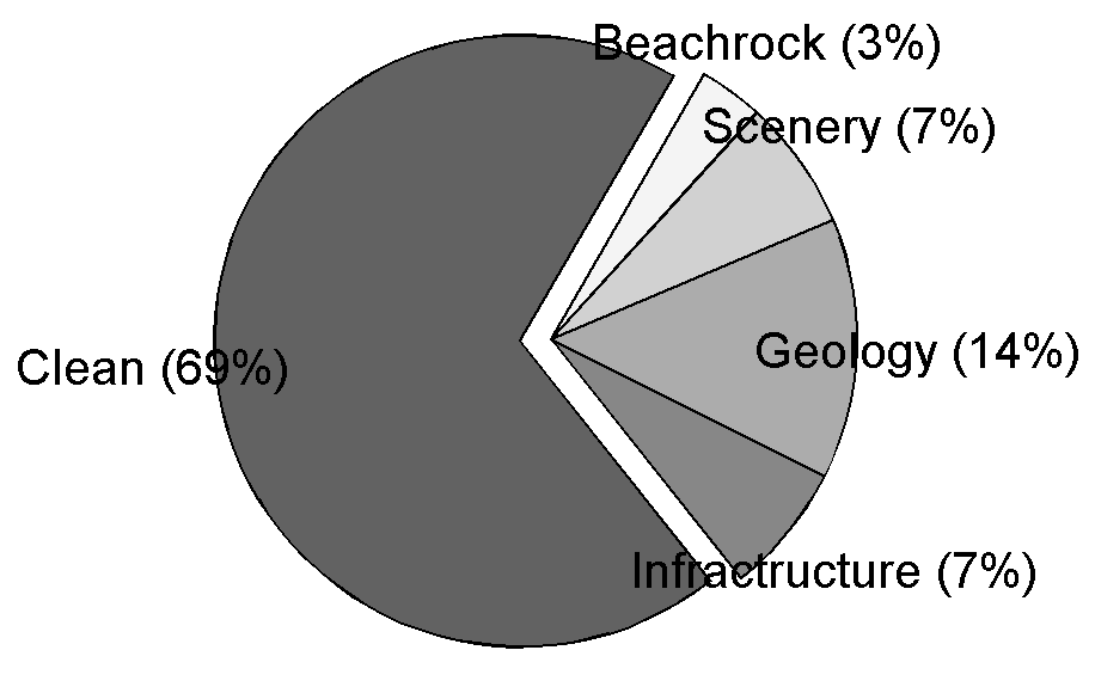

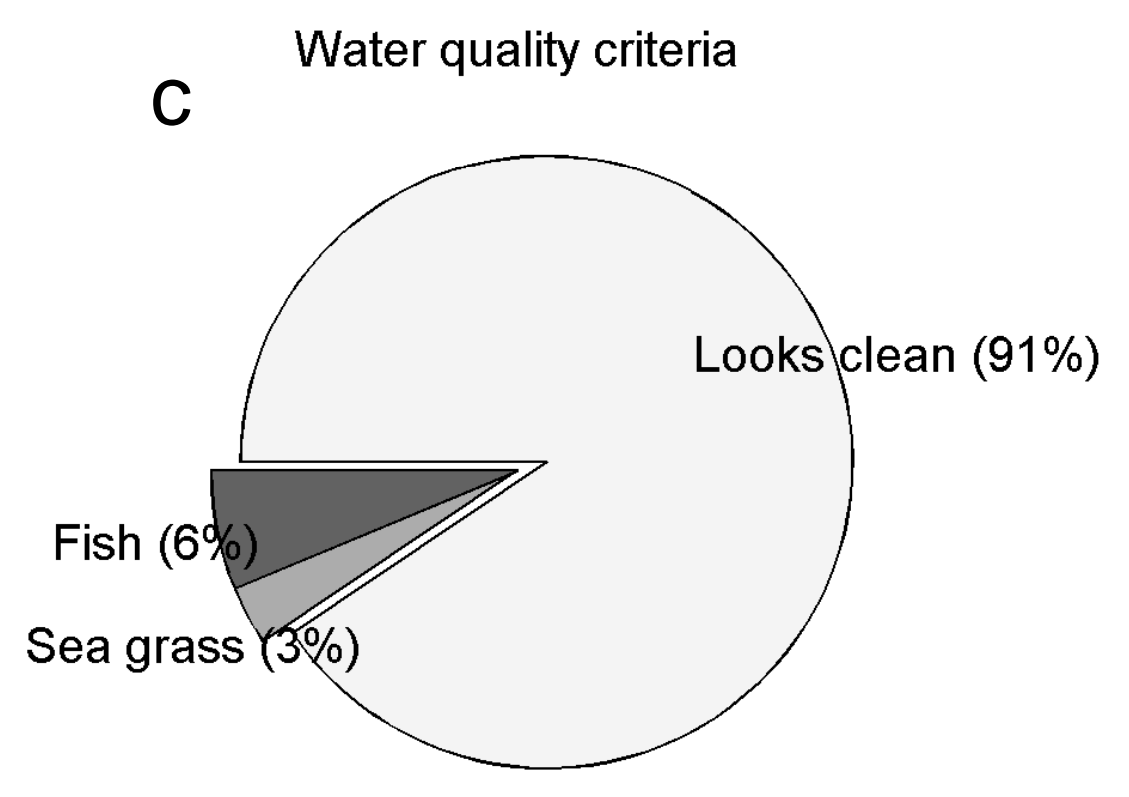




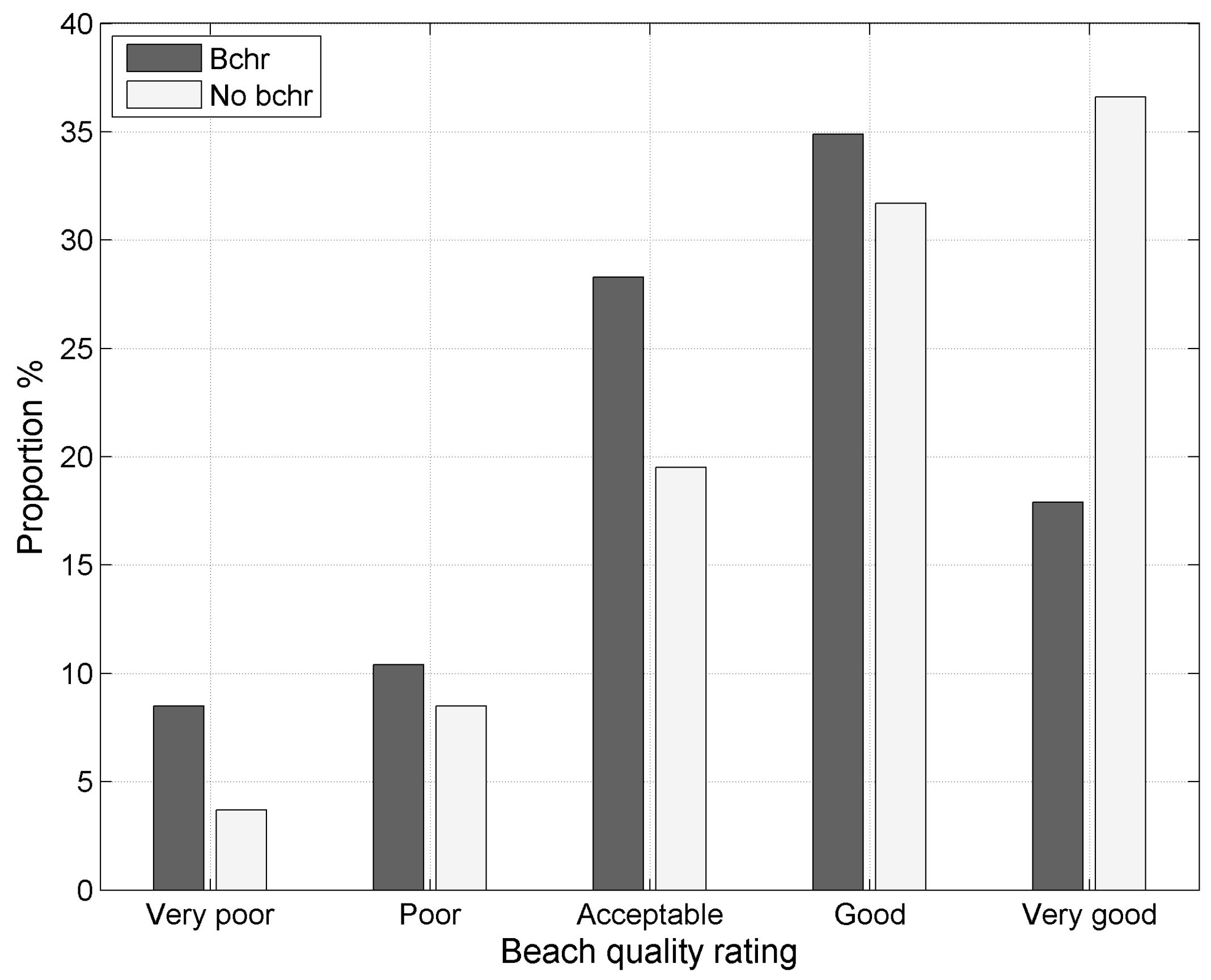


a

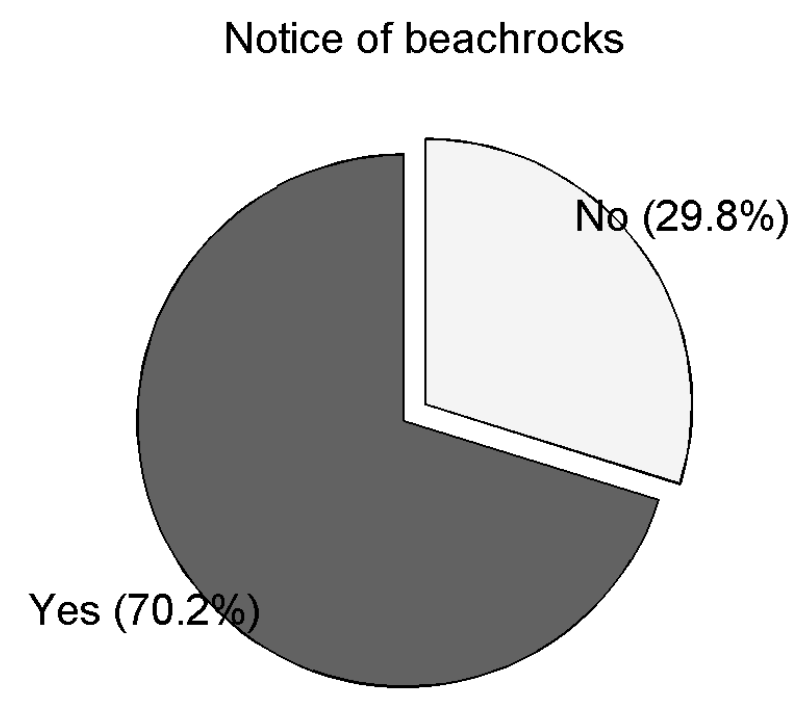

Need for protection measures

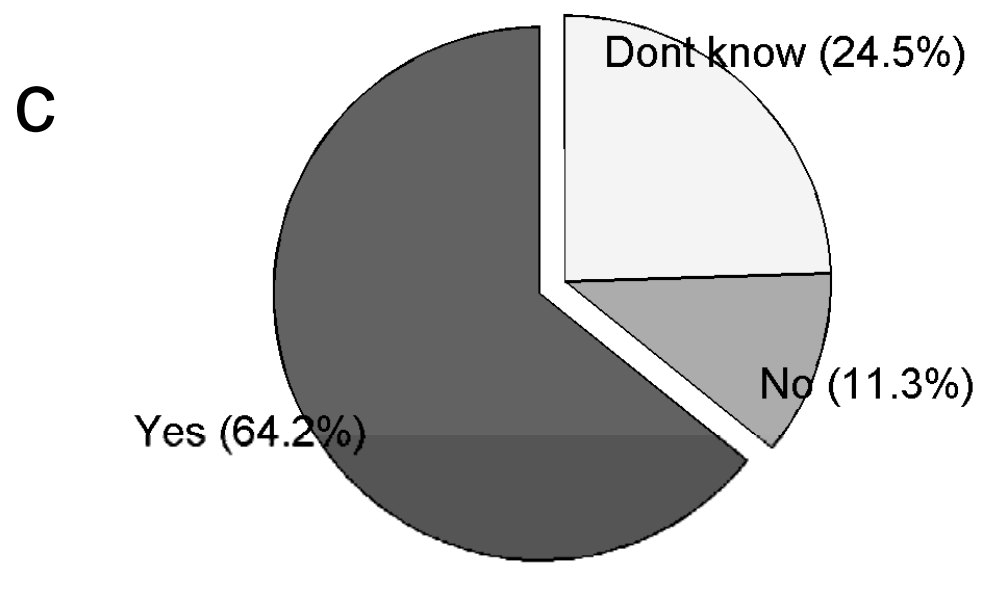

b

Prior knowledge

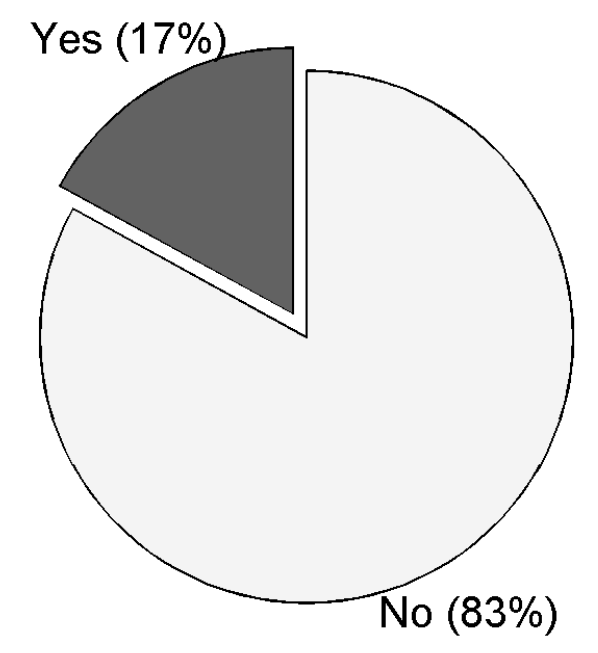

Need for prevention measures

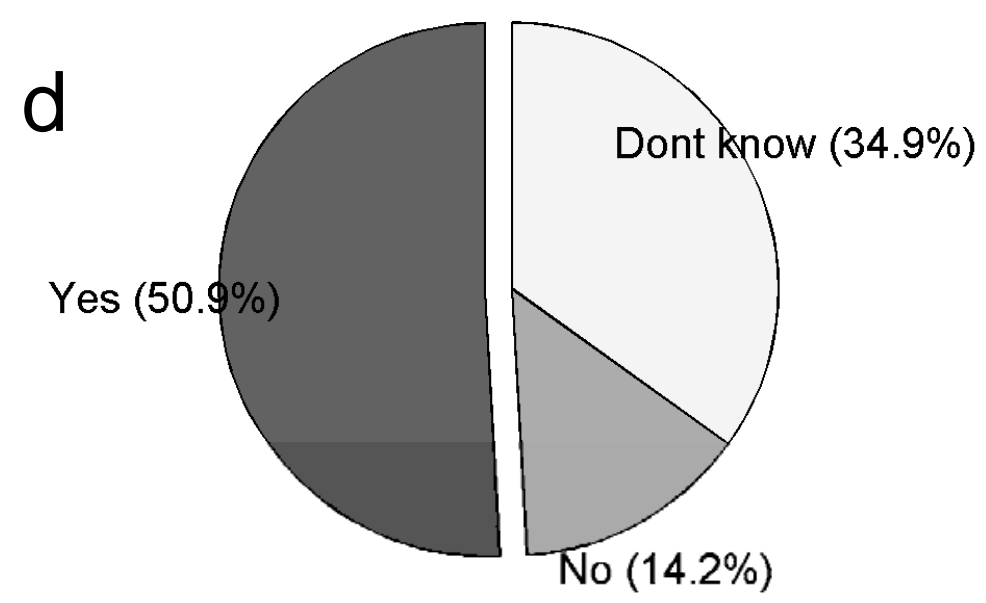


Difficulty to enter the sea

a

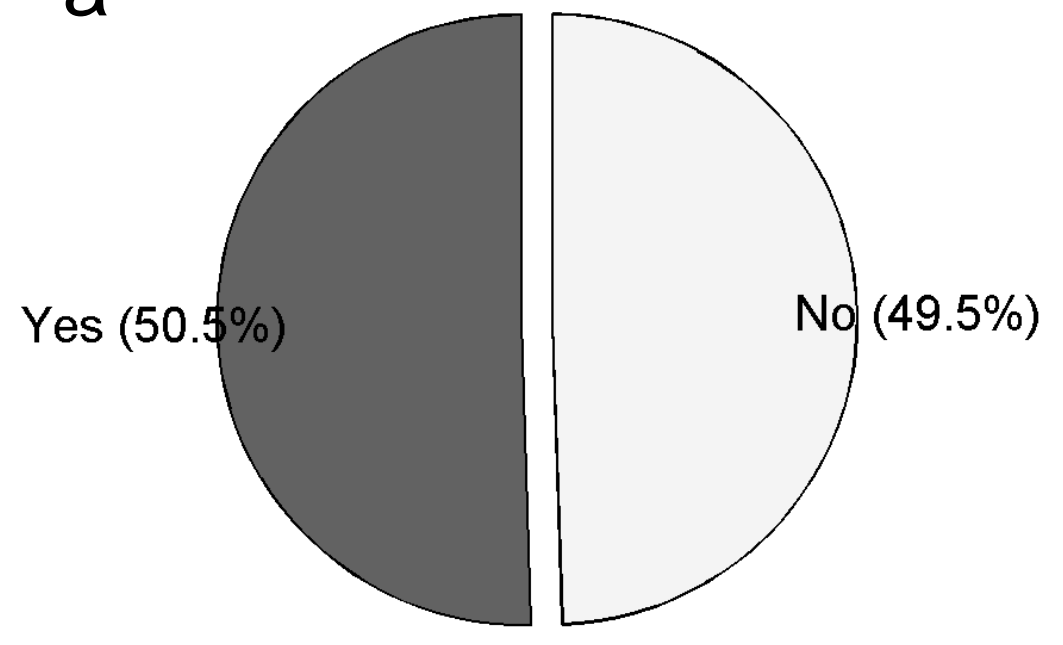

Reason to avoid the beach

C

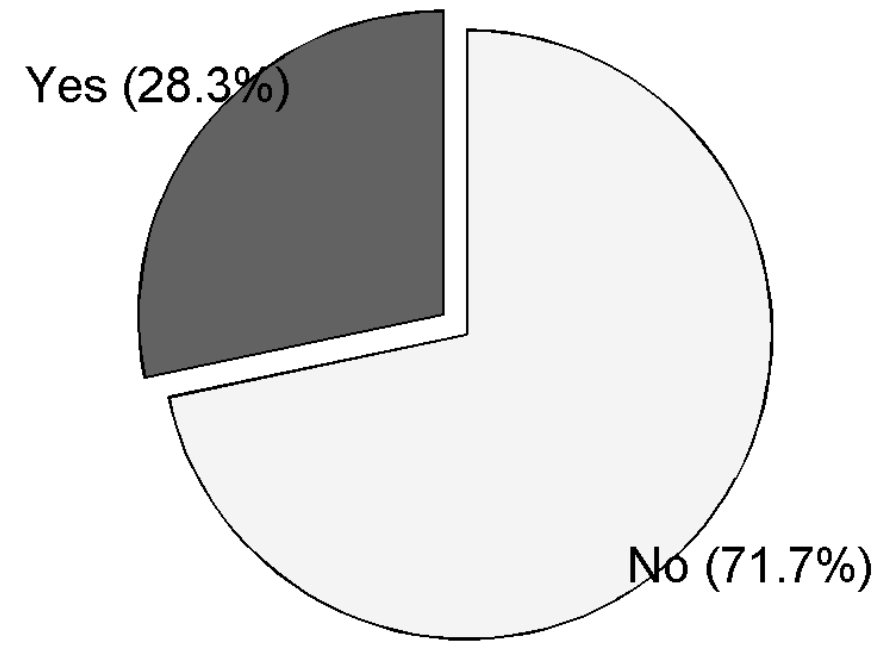

Accident

b

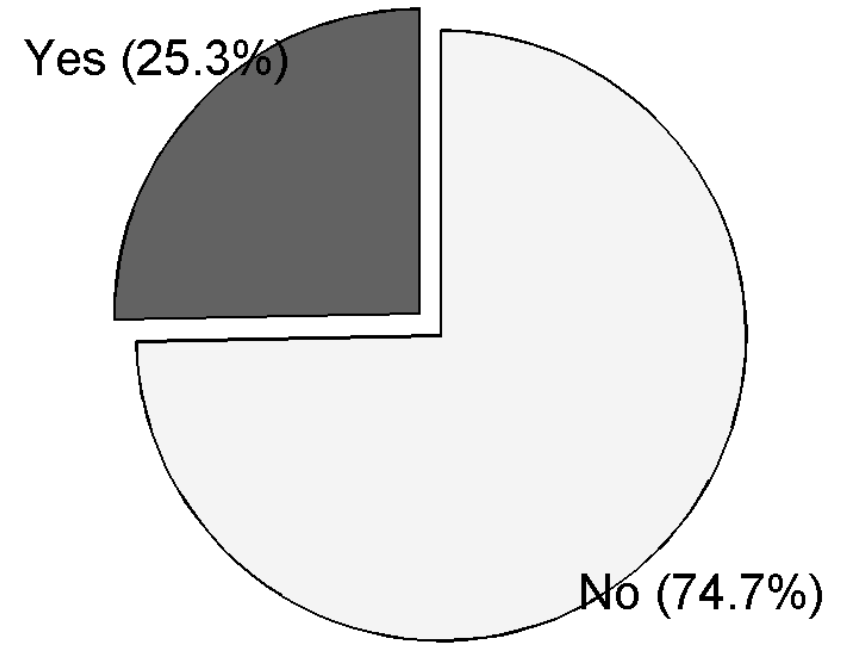

Reason to avoid in case of propagation

d

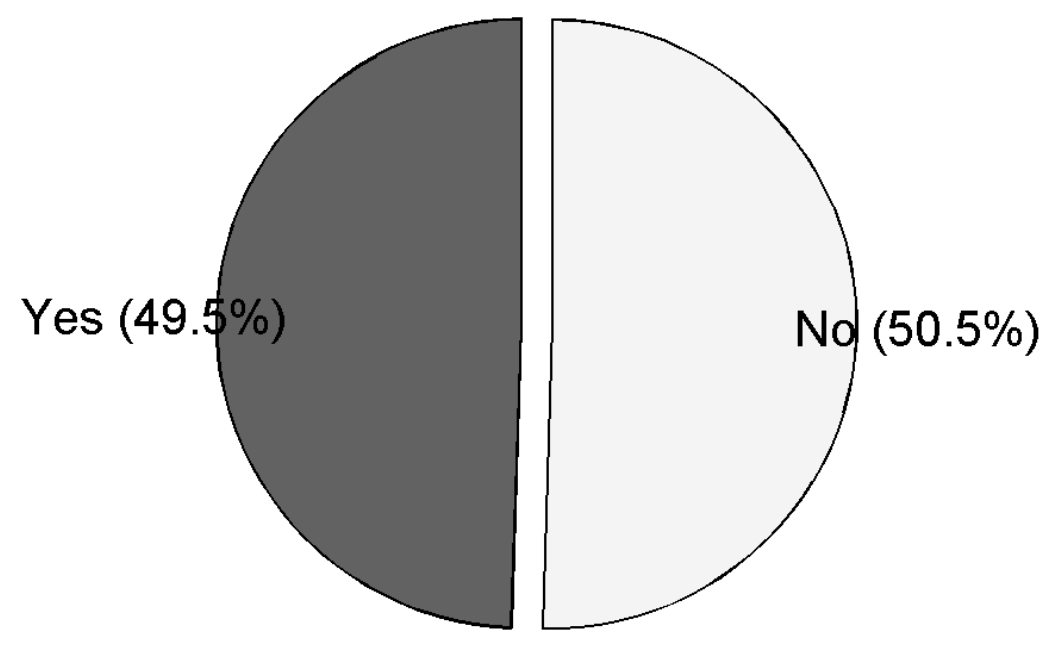



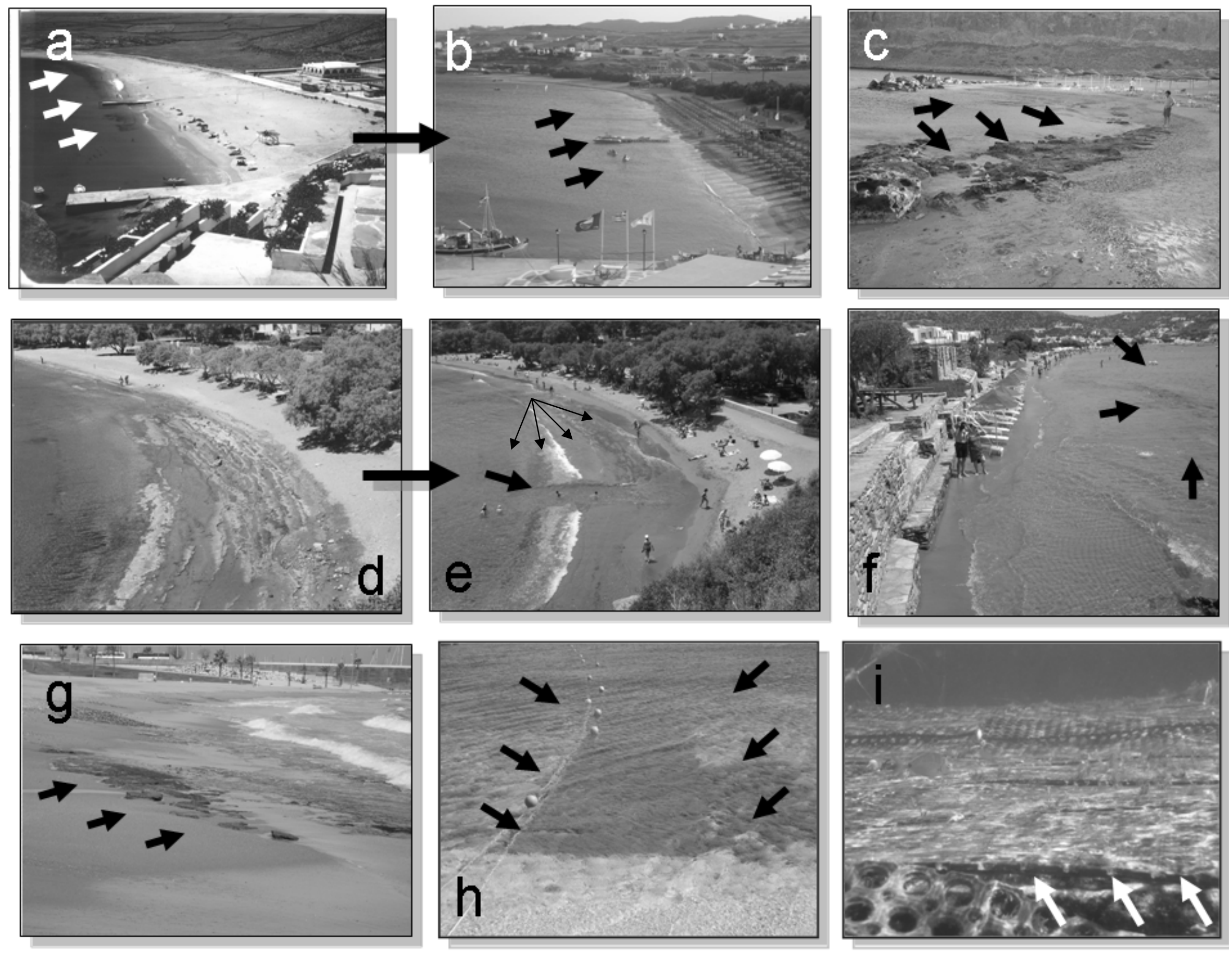

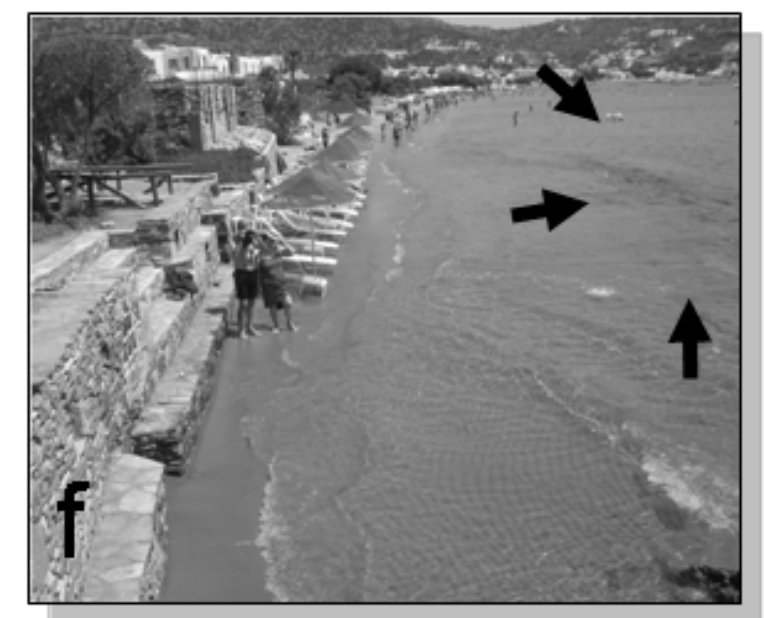
yom xum y

$\uparrow$ 
Figure 7

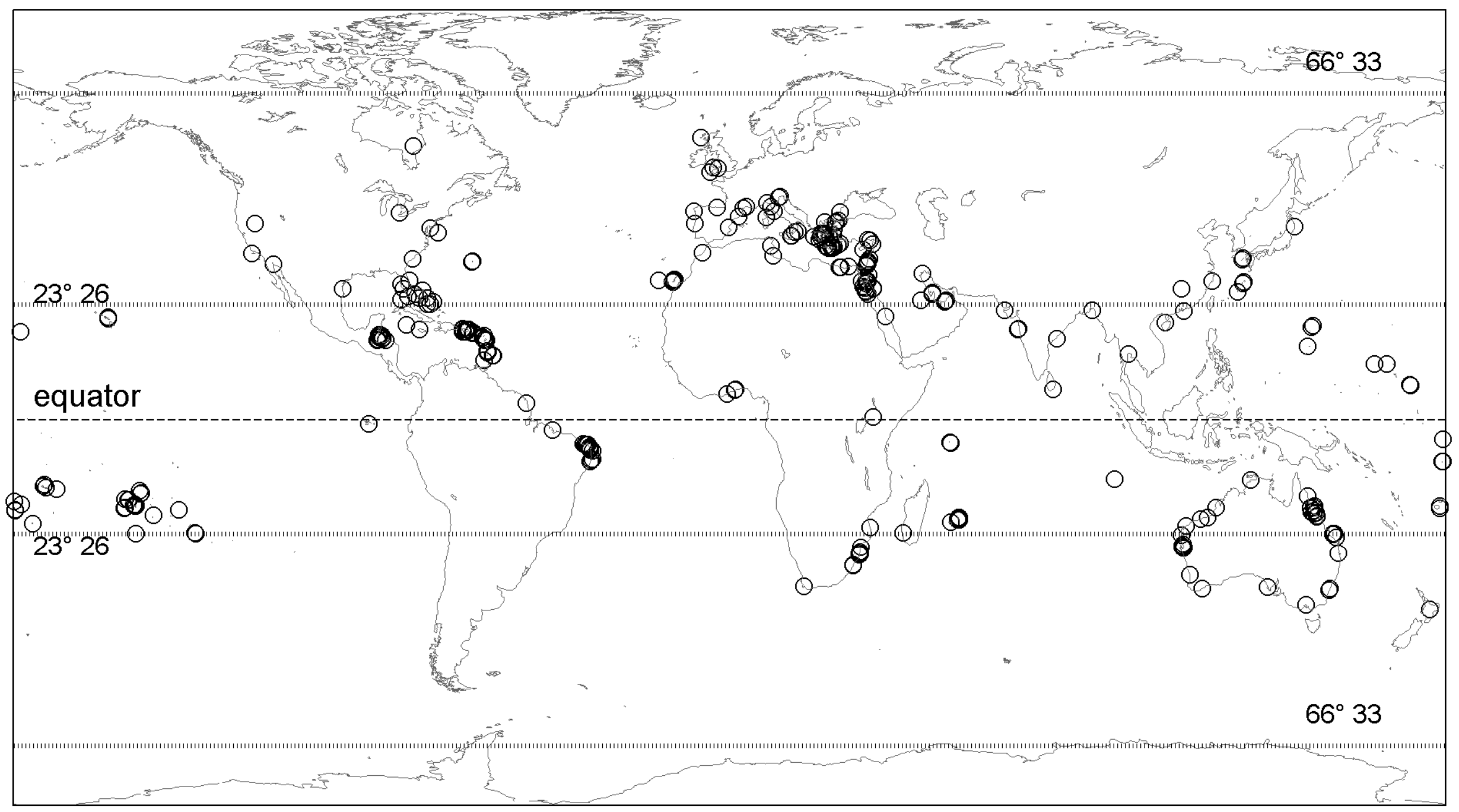




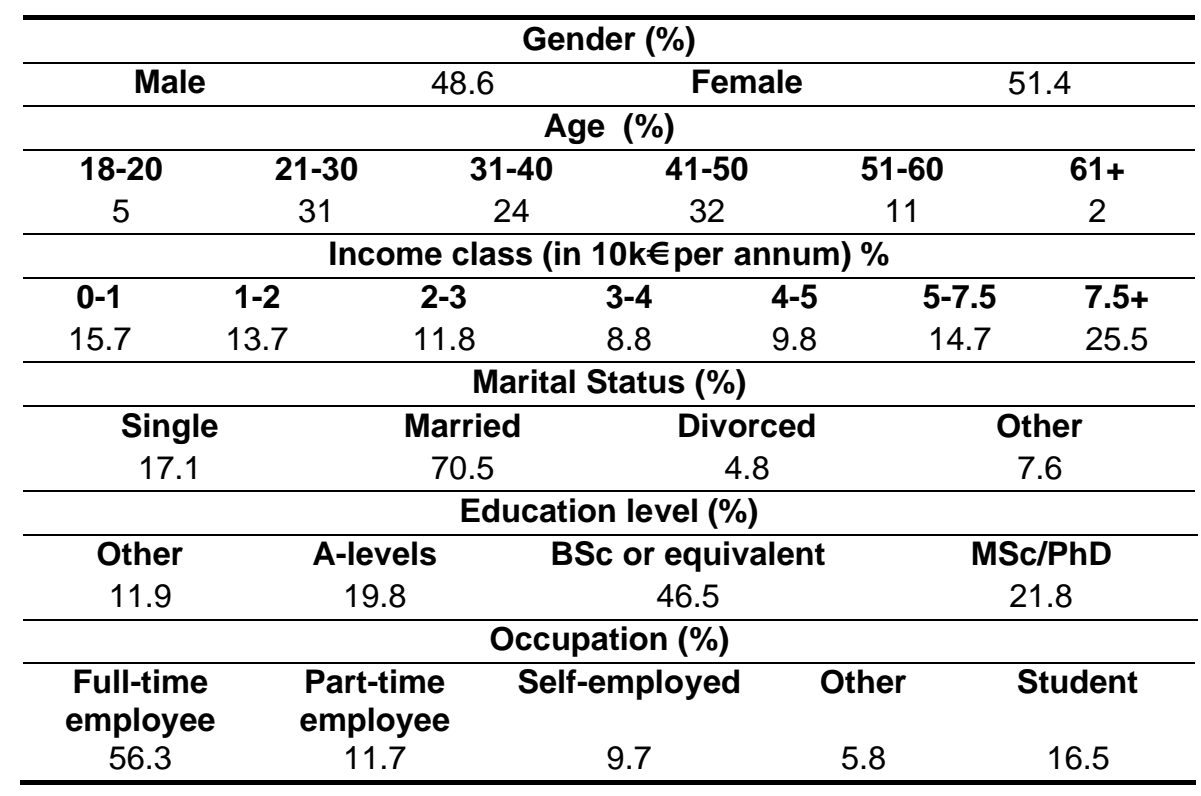




\begin{tabular}{lccccc}
\hline Risk Perception & $\begin{array}{c}\text { Very } \\
\text { low } \\
\text { risk }\end{array}$ & $\begin{array}{c}\text { Low } \\
\text { risk }\end{array}$ & $\begin{array}{c}\text { Medium } \\
\text { risk }\end{array}$ & $\begin{array}{c}\text { High } \\
\text { risk }\end{array}$ & $\begin{array}{c}\text { Very } \\
\text { high } \\
\text { risk }\end{array}$ \\
Food additives & $33 \%$ & $31 \%$ & $24 \%$ & $7 \%$ & $5 \%$ \\
Air pollution & $34 \%$ & $23 \%$ & $20 \%$ & $12 \%$ & $11 \%$ \\
Smoking & $13 \%$ & $14 \%$ & $20 \%$ & $17 \%$ & $36 \%$ \\
HIV infection & $38 \%$ & $23 \%$ & $13 \%$ & $9 \%$ & $17 \%$ \\
Nuclear power & $52 \%$ & $14 \%$ & $17 \%$ & $9 \%$ & $8 \%$ \\
Beachrocks & $48 \%$ & $27 \%$ & $15 \%$ & $6 \%$ & $4 \%$ \\
Mobile phone risks & $41 \%$ & $21 \%$ & $22 \%$ & $9 \%$ & $7 \%$ \\
Driving & $16 \%$ & $27 \%$ & $25 \%$ & $25 \%$ & $7 \%$ \\
Sunbathing & $25 \%$ & $22 \%$ & $35 \%$ & $13 \%$ & $5 \%$ \\
Terrorist activity & $41 \%$ & $21 \%$ & $15 \%$ & $11 \%$ & $12 \%$ \\
\hline
\end{tabular}




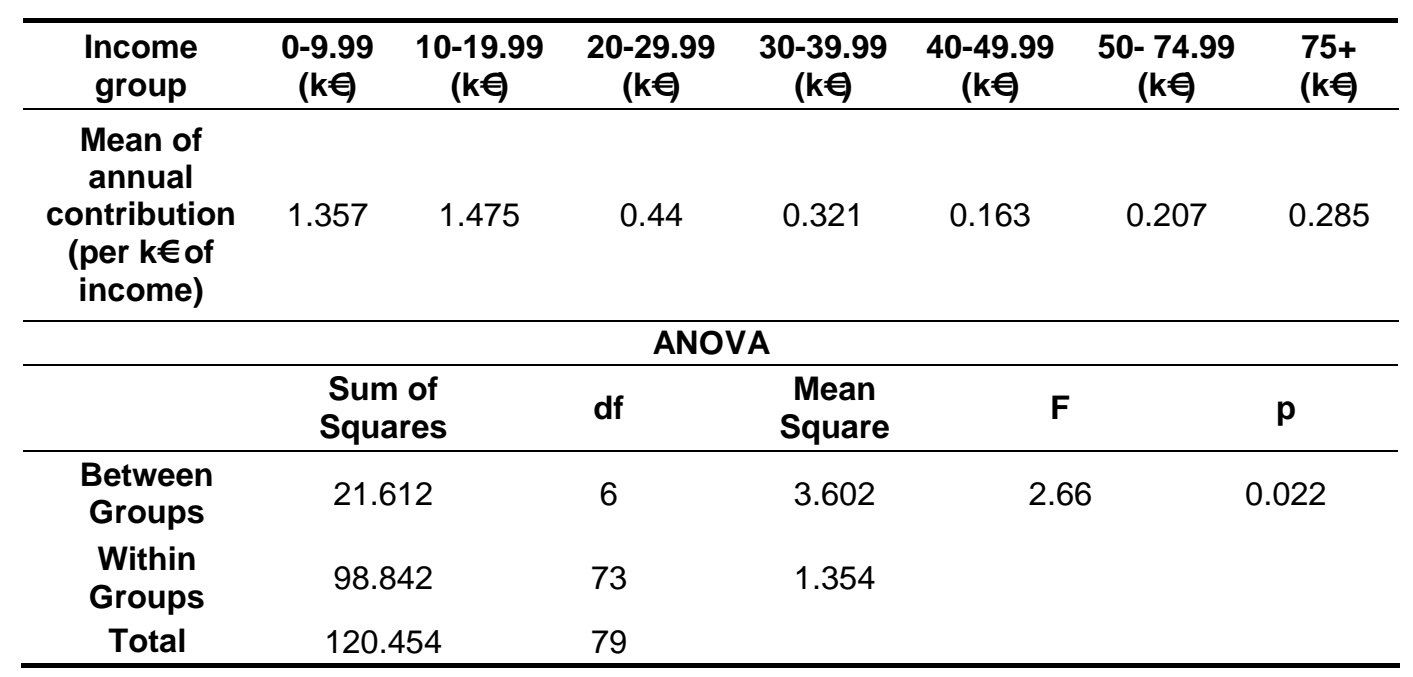




\begin{tabular}{cccccc}
\hline Gender & Male & Female & Male & Female \\
\hline $\begin{array}{c}\text { Mean of } \\
\text { annual } \\
\text { contribution }\end{array}$ & $9.19 €$ & $29 €$ & $\begin{array}{c}\text { Mean of annual } \\
\text { contribution } \\
\text { per k€ income }\end{array}$ & $0.16 €$ & $1.16 €$ \\
\hline & $\begin{array}{c}\text { Sum of } \\
\text { Squares }\end{array}$ & df & Mean Square & F & p \\
\hline $\begin{array}{c}\text { Between } \\
\text { Groups } \\
\text { Within } \\
\text { Groups } \\
\text { Total }\end{array}$ & 84426.5 & 80 & 8029 & 7.61 & 0.007 \\
\hline
\end{tabular}

